L. M. Kondratyeva, O. S. Shadrina, Z. N. Litvinenko, and E. M. Golubeva. Biogeochemical investigations of the speleothem moonmilk in the karst Proschalnaya Cave (Far East, Russia). Journal of Cave and Karst Studies, v. 82, no. 2, p. 95-105. DOI:10.4311/2019MB0106

\title{
BIOGEOCHEMICAL INVESTIGATIONS OF THE SPELEOTHEM MOONMILK IN THE KARST PROSCHALNAYA CAVE (FAR EAST, RUSSIA)
}

\author{
L. M. Kondratyeva', O. S. Shadrina', Z. N. Litvinenko ${ }^{1, C}$, and E. M. Golubeva ${ }^{2}$
}

\section{Abstract}

Results of investigations of natural waters (drip and fracture) and speleothem moonmilk from the karst Proschalnaya Cave (Russia, Far East) are reported. Concentrations of Fe and Mn in drip water were highest in spring, while the concentration of $\mathrm{Mn}$ was lowest in the fracture water, which may be due to the nature of infiltration of water through different channels after spring snowmelt and autumn rains. Molecular genetics investigation of the moonmilk mass revealed the presence of iron bacteria of the genera Rhodoferax and Geothrix. The visually plastic and homogeneous mass of moonmilk was shown to be highly heterogeneous, containing various microstructures. Tubular microstructures had a richer elemental composition ( $\mathrm{C}, \mathrm{O}, \mathrm{Ca}, \mathrm{Fe}, \mathrm{Mn}, \mathrm{Si}, \mathrm{Al}$, and $\mathrm{S}$ ), in comparison with claviform formations $(\mathrm{C}, \mathrm{O}, \mathrm{Ca}$, and $\mathrm{Na}$ ). Binding matrix in the composition of moonmilk is represented by reticular structures similar to nanofibers. The results of this research conducted in a monsoon climate may be interesting for speleologists working with karst caves in other climatic conditions.

\section{Introduction}

Microbes present in the specific habitats of aquifers and pore space of rocks play an important role in the processes occurring in the water-rock contact zone (Perry et al., 2004). Various organic compounds and microorganisms that are capable of colonizing the surface of rocks enter karst caves from the ground biotopes with infiltration waters (Chelius et al., 2009). However, the cave microbial composition varies by the types and configuration of caves (Barton et al., 2004; Velikonja et al., 2014) and depends on the sampling location (Ghosh et al., 2017).

As the results of analysis of microbial communities sampled from the walls of caves located in Spain, Czech Republic, and Slovenia, Porca et al., (2012) proposed the hypothesis that the colonization of caves with microorganisms occurred through water infiltration from the overlying rock and soil. The heterogeneity and main mechanism of microbial diversity in caves are well-connected with surface environments (Wu et al., 2015). Microbial exopolysaccharides, alginate acids, siderophores, and other chelating compounds act as important factors determining the colonization and dissolution rate of mineral rocks (Perry et al., 2004; Ercole et al., 2007; Kuhn et al., 2014).

Alternatively, microbial cells have been shown to act as centers for precipitation and crystallization of many elements (Barton and Northup, 2007). Microorganisms are also capable of altering the mineral composition and solubility of carbonates, as well as crystal size and morphology, as demonstrated by the large, poorly soluble $\mathrm{CaCO}_{3}$ crystals formed in the presence of Bacillus pasteurii (Mitchell and Ferris, 2006).

Dissolution of carbonate minerals and morphogenesis of karst cavities may be partially explained by bacterial activity (Hill and Forti, 2007). Infiltration, flood water, and airflow also introduce microbes into caves, where they can begin to influence the structure of the microbial community of caves. As weather parameters and water conditions change, the introduced microbial pool may also change strongly. As in surface environments, microorganisms act as active and passive promoters of redox reactions in the sedimentary processes in caves (dissolution, redeposition, secondary formation of minerals with participation of microorganisms) (Fornós et al., 2014).

The investigation of karst caves is presently carried out in several fields, including speleology, geology, and ecology. Research varies from large-scale analyses of landforms and processes involved in the formation of karst landscapes, to speleothems, including stalactites and stalagmites, to microscopic investigation of sinter formations. Among speleothems, moonmilk is a formation of high interest (Borsato et al., 2000; Cacchio et al., 2014). Moonmilk, one of the most common types of carbonate deposits (speleothems) formed in caves, has long been known as a habitat for microorganisms that are thought to be responsible for the origin of these commonly white and soft secondary calcite deposits (Reitschuler et al., 2016). Various forms of moonmilk deposition have been described, including encrustations, films, thick layers, deposits, and veins in clay. The metabolic activity of complex microbial communities can play an important role in the formation of moonmilk (Portillo and Gonzales, 2011).

The presence of microorganisms in moonmilk formations has been observed in caves around the world, from the tropics to high latitudes. It has been found that microbes participate in formation of the white and soft secondary calcite (calcium carbonate) deposits that can coat the walls, floors, and ceilings of caves. In this biologically-driven process,

\footnotetext{
${ }^{1}$ Institute of Water and Ecology Problems, Far Eastern Branch, Russian Academy of Sciences, Khabarovsk, 680000 Russia

${ }^{2}$ Institute of Tectonics and Geophysics, Far Eastern Branch, Russian Academy of Sciences, Khabarovsk, 680000 Russia

cCorresponding Author: zoyalitvinenko@gmail.com
} 
upper surface layers are actively formed, while the deeper and older parts become progressively dehydrated, encrusted, and inactive (Canaveras et al., 2006).

Moonmilk is primarily water by mass (60-90\%). In this geochemical environment, microbial cells can act as centers of precipitation and crystallization for many elements (Barton and Northup, 2007). As $90 \%$ of Earth's biomass resides in the subsurface, and many of those environments are exposed to constantly cold conditions (below $5{ }^{\circ} \mathrm{C}$ ), basic research on exotic habitats such as moonmilk through cultivation of microorganisms and geochemical analyses is important for understanding potentially widespread processes (Rodrigues and Tiedje, 2008). Low-temperature biotopes are successfully colonized by cold-adapted organisms, which include a large range of representatives from all three domains: Bacteria, Archaea, and Eukarya. As a result, psychrophiles are the most abundant in terms of biomass, diversity, and distribution (Struvay and Feller, 2012). The ability of psychrophilic microorganisms to grow at temperatures below $5{ }^{\circ} \mathrm{C}$ can be associated with their successful adaptation to the natural habitat. It is known that the microbial activity of psychrophiles and growth yield at low temperatures is higher than the growth rate at what is normally considered the optimal growth temperature (Margesin, 2009).

Microorganisms utilize several metabolic strategies to survive in the cave environment, such as synthesis of new organic matter from inorganic carbon (chemolithoautotrophy) and decomposition of organic matter (heterotrophy) (Chen et al., 2009). These processes, or its byproducts, can play a role in the transformation of rock through dissolution or formation of minerals (Lefevre et al., 2016).

Based on past studies conducted in the Snezhnaya Cave (Abkhazia) (Kondratyeva et al., 2016), it was hypothesized that the elemental composition of groundwater and the structure of microbial communities play a key role in determining the elemental composition of the moonmilk. Our research is devoted to the study of the elemental composition of groundwater and moonmilk, as well as the activity of microorganisms in the Proschalnaya Cave (Far East, Russia).

Investigation of moonmilk from Proschalnaya Cave was conducted in two stages: (1) microbiological research (molecular genetic techniques, isolation of cultured bacterial strains, determination of their physiological and biochemical activity) and (2) the analysis of nanostructures in the moonmilk mass by scanning electron microscopy with determination of their elemental composition.

The main objective of our research was to determine environmental factors that characterized pecularities of biofilm from moonmilk in a large karst cave on the Far East of Russia. For the first time interdisciplinary studies including physicochemical, microbiological, molecular genetic methods, and scanning electron microscopy of moonmilk from the Proshalnaya Cave were conducted. The results of research on biofilm and rock interactions in a monsoonal climate can be interesting for speleologists working with karst caves in other climatic conditions.

\section{Materials and Methods}

\section{Sampling site}

Proschalnaya Cave is on the eastern slope of the Sagdi-Selanka River valley (Amur River Basin) in the Khabarovsk

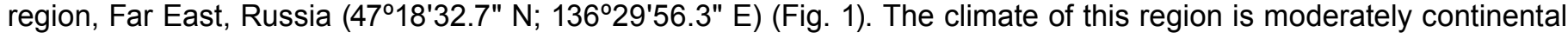
with signs of monsoonal: humid summers with frequent rains and winter with little snow. A monsoonal climate is characterized by a sharp contrast in the amount of precipitation over the year seasons and stability of the wind direction for one season with a sharp wind variation in the opposite direction during changing seasons. The cave is remote from settlements, not visited by tourists, and accessible for speleologists only. The cave does not have access for animals due to the complex labyrinths and deep depth.

The cave is a labyrinth with a total length of approximately $6 \mathrm{~km}$, multiple levels, and a large number of halls, galleries, and grottos. There is a watercourse and many sources of drip and fracture water inside the cave; the walls and ceilings are covered with various speleothems, including moonmilk (Fig. 2). The chemical composition of the karst waters of the Russian Far East are primarily hydrocarbonate-calcium , and more rarely, chloride-hydrocarbonate-calcium with an average degree of mineralization (5-15 g/L) (Bersenyov, 1989). Surface waters of the Sagdi-Selanka River and groundwaters of Proschalnaya Cave are characterized by an increased content of Ca ions (82-86 \% mg-Eq) and a very low concentration of $\mathrm{Mg}$ ions (9-12\% mg-Eq) (Shesterkin, 1983). Hydrochemical studies of natural waters in the Proschalnaya Cave have not been carried out in recent years.

\section{Sampling characterization}

In May 2015, 2016, and 2017 and in November 2015, water samples of different origins were taken from the cave (watercourse, drip, and fracture water) and from the Sagdi-Selanka River (surface water) according to the standards of sampling in hydrochemistry and microbiology (Gerhardt, 1983; Kuznetsov and Dubinina, 1989). In the study area, the average amount of precipitation during the month was: $105 \mathrm{~mm}$ in May 2015; $136 \mathrm{~mm}$ in May 2016, and $48 \mathrm{~mm}$ in May 2017. In November 2015, precipitation was minimum, $9.9 \mathrm{~mm}$. In the cave air temperature was $1-4{ }^{\circ} \mathrm{C}$. 


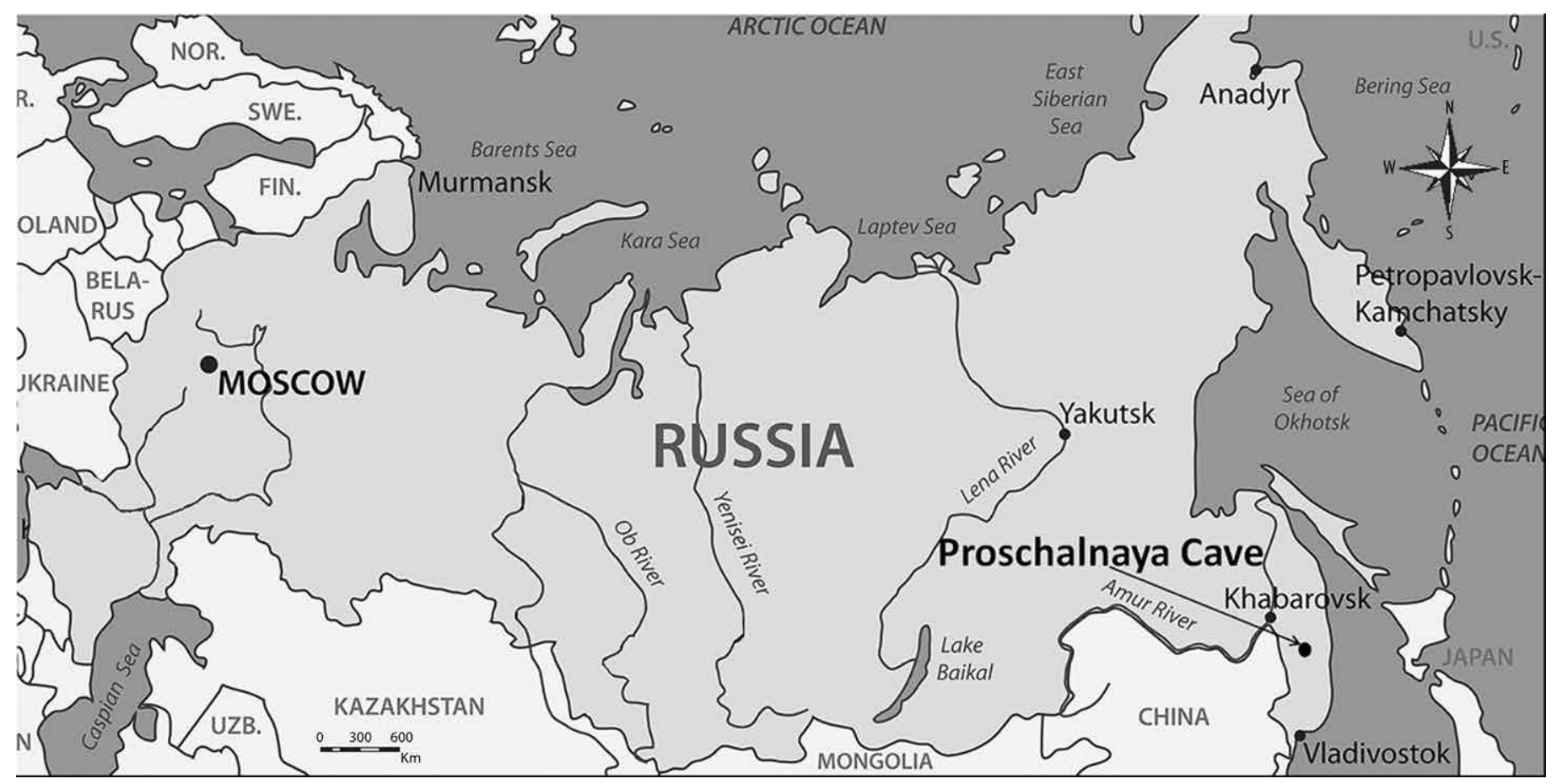

Figure. 1. Geographical location of the Proschalnaya Cave in the Amur River Basin, Khabarovsk region (Far East, Russia).
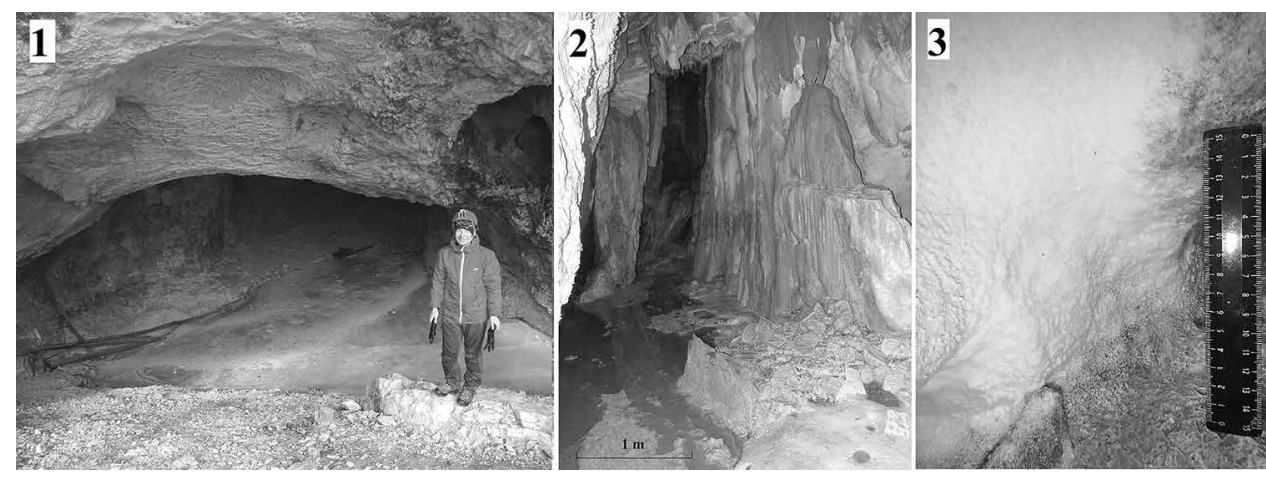

Figure. 2. Proschalnaya Cave (Russia): (1) Entrance to the cave, (2) Gallery in the Albatross system, (3) moonmilk on the wall (M2 - thick curdy ivory-white mass).
In the Marble room, samples of moonmilk deposits of different consistencies were aseptically collected in sterile tubes: M1thin slimy white mass and M2thick curdy ivory-white mass were taken from the walls; M3-dry white mass was taken from the surface of broken rocks. Samples were transported to the laboratory in coolers at $4{ }^{\circ} \mathrm{C}$.

Determination of the elemental composition in samples of natural waters and moonmilk was carried out with use of the Total Quant out with use of the

ICP-MS method, PerkinEImer (USA), in accordance with standard methods (Federation Regulation, 2011).

\section{Microbial studies}

For the inoculum, $100 \mathrm{mg}$ of wet mass of moonmilk was dispersed in $10 \mathrm{~mL}$ of sterile physiological saline; dilution was performed in 100 -fold and $0.1 \mathrm{~mL}$ of suspension was used for spread-plating on the agar culture media. The abundance of heterotrophic and Fe-metabolizing cultivated bacteria (CFU/mL) in natural waters and in moonmilk was determined on the 7 th day after cultivation on solid nutrient media with use of spread plates at $23^{\circ} \mathrm{C}$ : SAA (starch ammonium agar) (Gerhardt, 1983); FPA (fish peptone agar) and FPA diluted 10 times (Kuznetsov and Dubinina, 1989); and Vinogradsky medium (Egorov, 1995). For the cultivation of Fe-metabolizing bacteria, Bromfield agar medium was used (Namsaraev et al., 2006).

Diagnostic system (SPA Microgen, Moscow, Russia) with color indicators and various carbon sources (carbohydrates, polyhydric alcohols, and amino acids) was used to determine the nutritional range of strains isolated from different types of water. The growth activity of the strains was evaluated by the color change of the dissolved substrate on the 7 th day after cultivation at $23^{\circ} \mathrm{C}$. Amylase activity was determined on SAA after treating the colonies with Lugol's solution according to the diameter of the starch hydrolysis zones. 


\section{qPCR analysis}

Microbial investigation of moonmilk samples (M1 and M2) were carried out with use of quantitative PCR (qPCR) analysis according to standard procedures (Kubista et al., 2006). DNA was extracted using a GeneMATRIX Soil DNA Purification Kit (Roboklon, Berlin, Germany). The total number of eubacterial DNA copies and the DNA copies of bacteria of the genera Rhodoferax and Geothrix were determined with use of specialized primers which were offered by Prof. U. Szewzyk (Technische Universität Berlin): Eubacteria (Uni338F_RC ACT CCT ACG GGA GGC AGC, Uni907R CCG TCA ATT CMT TTG AGT TT); Rhodoferax ferrireducens group (RdoR_RC GAC CTG CAT TTG TGA CTG YA, Uni907R CCG TCA ATT CMT TTG AGT TT), Geothrix (Gx. 193F_GAC CTT CGG CTG GGA TGC TG, Gx. 448R_AGT CGT GCC ACC TTC GT) (Braun et al., 2016). Quantitative PCR was performed with an RG-6000-5 Plex real-time DNA cycler (Rotor-Gene 6000). Non-DNA-containing samples were used as negative controls to ensure the accuracy of the qPCR. Cycles of qPCR characterized: 40 cycles for Eubacteria (Initial denaturation $95^{\circ} \mathrm{C}, 2$ min; Denaturation $95^{\circ} \mathrm{C}$, $20 \mathrm{~s}$; Annealing $60.4^{\circ} \mathrm{C} 30 \mathrm{~s}$; Extension $72^{\circ} \mathrm{C}, 1 \mathrm{~min}$ ); 40 cycles for Rhodoferax ferrireducens (Initial denaturation 95 ${ }^{\circ} \mathrm{C}, 2 \mathrm{~min}$; Denaturation $95^{\circ} \mathrm{C}, 20 \mathrm{~s}$; Annealing $58^{\circ} \mathrm{C}, 30 \mathrm{~s}$; Extension $72{ }^{\circ} \mathrm{C}, 1 \mathrm{~min}$ ); 45 cycles for Geothrix fermentans (Initial denaturation $95^{\circ} \mathrm{C}, 3 \mathrm{~min}$; Denaturation $95^{\circ} \mathrm{C} 20 \mathrm{~s}$; Annealing $58^{\circ} \mathrm{C}, 20 \mathrm{~s}$; Extension $72{ }^{\circ} \mathrm{C}, 30 \mathrm{~s}$ ). Quantification was performed using standard curves obtained from the amplification profiles of known concentrations of the respective standard. A melt curve analysis $\left(55-99^{\circ} \mathrm{C}\right)$ was performed at the end of PCR cycles to confirm specificity of primer annealing. The parameters for the calibration curves were $R^{2}>0.99$, efficiency from $92 \%$ to $98 \%$.

\section{Scanning electron microscopy}

Textural and microstructural characterization of moonmilk was performed using a VEGA 3 LMH TESCAN scanning electron microscope (Czech Republic). The samples were prepared by air drying, and Pt coating. Then the moonmilk samples were placed on a conductive carbon tape, mounted on $12 \mathrm{~mm}$ diameter aluminum stubs that were then placed in the microscope chamber; magnification was up to 15,000x. Energy dispersive spectrometer X-max 80 with Aztec $^{\mathrm{TM}}$ microanalysis system (Oxford Instruments, UK) was used for the elemental composition analysis of moonmilk. X-Max 80 provides a range of detected elements from boron to uranium with elements detection interval from 0.1-100 wt. \%. The general process for sample preparation and scanning electron microscopy were carried out at the Khabarovsk Innovation and Analytical Center for Collective Use at the Institute of Tectonics and Geophysics, Far East Branch, Russian Academy of Science.

\section{Results and Discussion}

\section{Elemental composition of water of different origins}

The content of $\mathrm{Ca}$ in drip and fracture water in the Proschalnaya Cave is dependent on the amount of precipitation. The maximum amount of $\mathrm{Ca}$ in drip and fracture water was recorded in May 2016 (Fig. 3) at maximum amount of precipitation (136 mm/month). High Ca content is associated with dissolution of calcium carbonates contained in rocks in interaction with natural waters, especially when the acidity of the water increases in the presence of organic matter (OM) and microbial metabolic activities in the overlying soils.

We have shown (Kondratyeva et al., 2016) that in vitro the process of dissolution of $\mathrm{CaCO}_{3}$ crystals was accelerated in the presence of nitrogen-containing OM. Microorganisms capable of synthesizing a polymer matrix played a determinative role. The formation of abundant slimy biofilms that formed on the surface of $\mathrm{CaCO}_{3} \mathrm{crystals}_{\text {contributed to }}$ their dissolution (Fig. 4). During cultivation of moonmilk suspensions on agar nutrient media, we often observed growth of slimy colonies of heterotrophic bacteria capable of consuming different sources of carbon. The polymer matrix produced by these bacteria may be an active accumulator of other elements forming the moonmilk mass. It is known that over $99 \%$ of microorganisms on Earth live within matrix consisting of a mixture of polymeric compounds (extracellular polymeric substance: EPS), which makes up the intercellular space of microbial aggregates and forms the structure and architecture of the biofilm matrix (Flemming, 2016).

$\mathrm{Fe}$ and $\mathrm{Mn}$ measurements for drip water were highest in the spring period. Enrichment of water with iron occurs as a result of leaching and dissolution of ferruginous minerals and rocks. Among the geochemical factors, ferric oxide was correlated with increased microbial diversity in the cave sediments (De Mandal et al., 2017). It should be noted seasonal asynchrony in the content of manganese in the drip and fracture water in the Proschalnaya Cave. In November 2015, the content of $\mathrm{Mn}$ in the fracture water was much higher than in the drip water and watercourses. In the spring of 2016, the concentration of manganese in the fracture water was lower than in other water samples, which may be due to the infiltration of water through different channels after spring snowmelt and autumn rains. Organic substances play an important role in determining the intensity of microbiological processes at the biogeochemical barrier of water-rock, which would also affect the content of dissolved forms of iron and manganese (Ferris, 2005). 
Ca

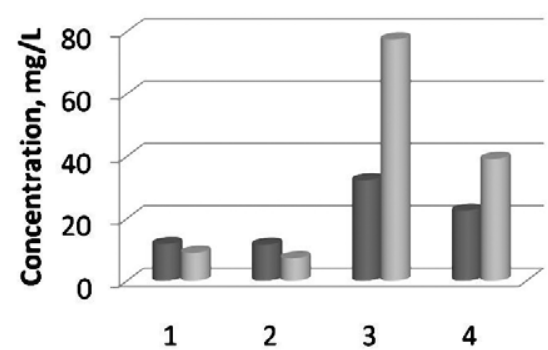

$\mathrm{Fe}$

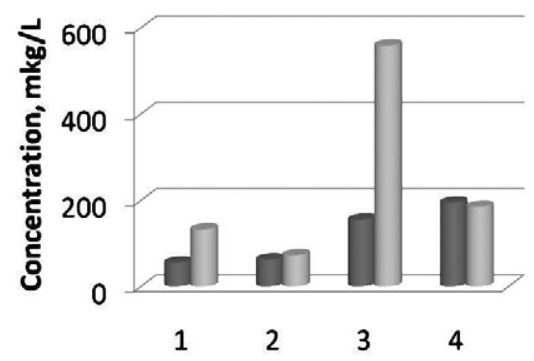

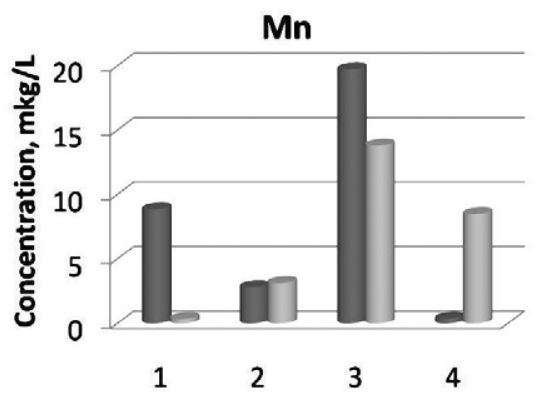

November, 2015 May, 2016

Figure. 3. The content of calcium, iron, and manganese in natural waters of different origins (November 2015; May 2016): (1) watercourse from the Proschalnaya Cave; (2) surface water from Sagdi-Selanka River; (3) drip water; (4) fracture water.

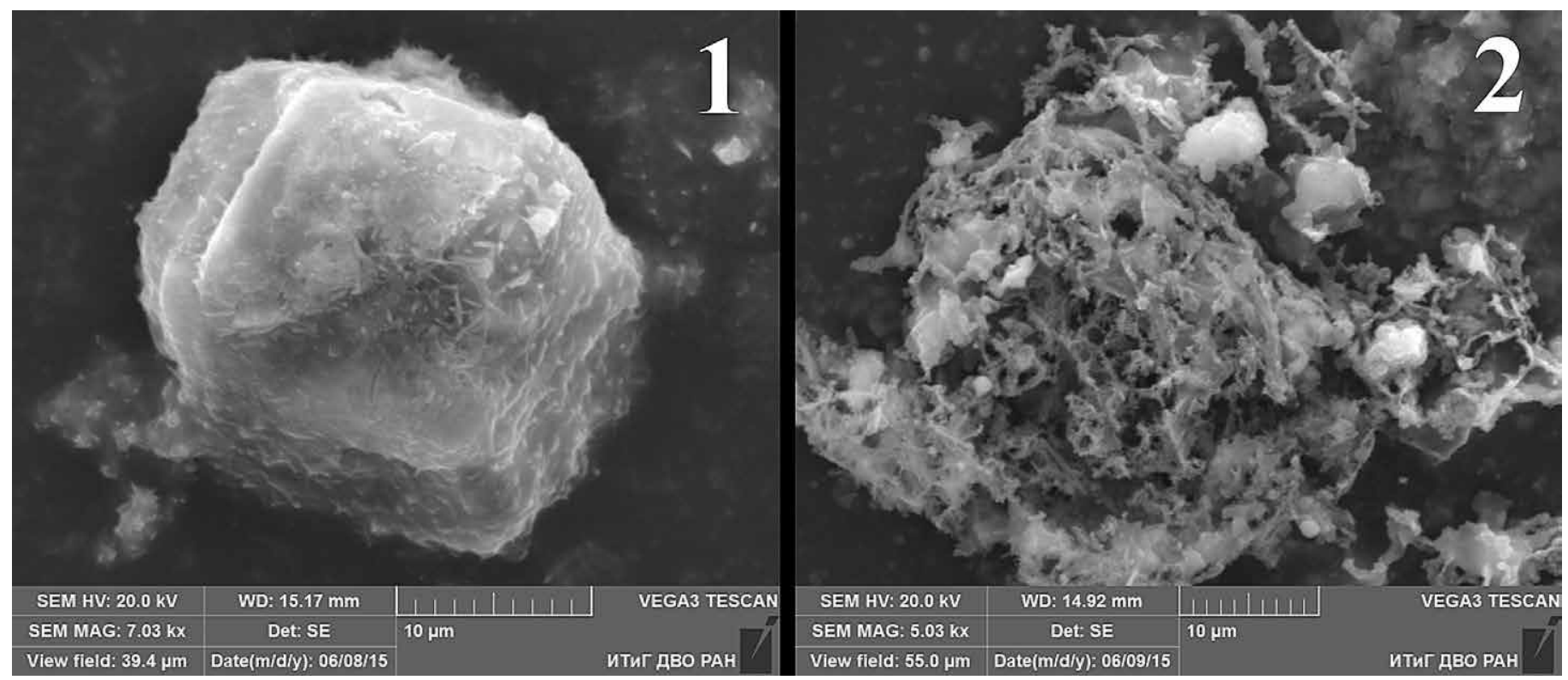

Figure. 4. SEM image of different stages of $\mathrm{CaCO}_{3}$ crystal dissolution: (1) stage of bacterial cells adhesion and the formation of EPS on the surface of the $\mathrm{CaCO}_{3}$ crystal; (2) final stage of complete dissolution of the crystal; formed biofilms retain the shape of the crystal in space.

\section{Microbiological studies of water}

In samples of water from the watercourse in the Proschalnaya Cave, regardless of the season, the predominant microorganisms preferred low concentrations of OM. Nitrifying and ferromanganese bacteria were also present in these samples. The most abundant microorganisms $\left(6.28 \times 10^{3} \mathrm{CFU} / \mathrm{mL}\right)$ were in the cave watercourse in the spring, likely due to the increased transport of easily oxidized OM from the soil during snowmelt. During this time, the number of microorganisms present in the samples of surface water from Sagdi-Selanka River was lower due to increased flow velocity and volume. Autumn sampling from the cave watercourse and river surface water revealed decreased numbers of all physiological groups of cultivated microorganisms.

Fifty strains were isolated from water samples on different media (FPA; FPA diluted 10 times; Vinogradsky media). Using cultural and morphological characteristics, ten strains with active growth on agar media were selected for the study of biochemical activity. Strains isolated from the surface water of Sagdi-Selanka River and fracture water were most active and capable of utilizing the monosaccharides $\beta$-galactose, glucose, mannose, arabinose, arginine, ornithine, and mannitol as a source of carbon (Table 1). Strains of bacteria isolated from the river surface water and watercourse in the cave recycled the disaccharides lactose and sucrose, associated with the enzyme carbohydrase, which is responsible for the hydrolysis of di-, tri-, and polysaccharides. This enzyme also plays a role in regulating equilibrium between different forms of inorganic carbon, including bicarbonate, which is involved in the precipitation of calcium in nature (Müller et al., 2014).

Some strains isolated from fracture water and one representative of drip water utilized various amino acids (arginine, lysine, and ornithine) as a carbon source. Strains from the cave watercourse and fracture water actively utilized alco- 
Table 1. Carbon utilization by the strains isolated from surface water of Sagdi-Selanka River and different water sources from the Proschalnaya Cave (May, 2017).

\begin{tabular}{|c|c|c|c|c|c|c|c|c|c|c|}
\hline \multirow[b]{3}{*}{ Source of Carbon } & \multicolumn{10}{|c|}{ Bacterial Strain per Water Source } \\
\hline & \multicolumn{3}{|c|}{$\begin{array}{l}\text { Surface water from } \\
\text { Sagdi-Selanka River }\end{array}$} & \multicolumn{2}{|c|}{$\begin{array}{c}\text { Watercourse } \\
\text { in Cave }\end{array}$} & \multicolumn{3}{|c|}{$\begin{array}{l}\text { Drip Water } \\
\text { in Cave }\end{array}$} & \multicolumn{2}{|c|}{$\begin{array}{c}\text { Fracture } \\
\text { Water } \\
\text { in Cave }\end{array}$} \\
\hline & B 44 & B 45 & B 46 & B 19 & B 21 & B 25 & B 26 & B 32 & B 38 & B 42 \\
\hline Glucose & + & + & + & + & + & + & - & + & + & + \\
\hline Mannose & + & + & + & + & + & + & + & + & + & + \\
\hline Arabinose & + & + & + & + & + & + & + & + & + & + \\
\hline Lactose & + & - & + & + & - & + & + & + & + & - \\
\hline Sucrose & + & - & - & + & - & + & - & - & + & - \\
\hline Arginine & + & + & + & + & + & + & + & + & + & + \\
\hline Lysine & - & - & - & - & - & + & - & - & + & + \\
\hline Ornithine & + & + & + & + & + & + & + & + & + & + \\
\hline Inositol & + & - & + & + & + & + & - & + & + & + \\
\hline Mannitol & + & - & + & + & + & - & + & + & + & + \\
\hline Sorbitol & - & - & + & + & + & + & + & + & + & + \\
\hline$\beta$-galactose & + & + & - & - & - & - & - & - & - & + \\
\hline Sodium malonate & + & - & + & + & + & + & + & + & + & + \\
\hline Sodium citrate & + & - & + & + & + & + & + & + & + & + \\
\hline Urea & - & - & + & - & + & + & - & + & - & + \\
\hline
\end{tabular}

Note: "+" is a positive reaction, "-“ is a negative reaction.

hols (inositol, sorbitol, and mannitol). Most strains were also capable of using citrates as a source of carbon. Overall, strains isolated from fracture water had the most flexible carbon requirements.

\section{Microbiological studies of the moonmilk}

The abundance of cultivated bacteria within moonmilk varies strongly depending on its consistency (Table 2). In all samples, heterotrophic microorganisms dominated, consuming high concentrations of nitrogen-containing organic

Table 2. Structures of the microbial communities of moonmilk of different consistency from the Proschalnaya Cave.

\begin{tabular}{|c|c|c|c|c|}
\hline \multirow[b]{2}{*}{ Media } & \multirow[b]{2}{*}{ Colony Morphotype } & \multicolumn{3}{|c|}{ Abundance of microorganisms, CFU/g $\times 1000$} \\
\hline & & $\begin{array}{c}\text { Sample No. M1 } \\
\text { (thin slimy white mass) }\end{array}$ & $\begin{array}{c}\text { Sample No. M2 } \\
\text { (thick curdy ivory-white mass) }\end{array}$ & $\begin{array}{l}\text { Sample No. M3 } \\
\text { (dry white mass) }\end{array}$ \\
\hline \multirow[t]{4}{*}{ FPA } & PR & $111 \pm 10.5$ & $142 \pm 16.8$ & $15 \pm 3.9$ \\
\hline & $\mathrm{PO}$ & $41 \pm 6.4$ & $5 \pm 2.2$ & $3 \pm 0.7$ \\
\hline & Y & $74 \pm 8.6$ & $3 \pm 0.7$ & $\cdots$ \\
\hline & Total & $226 \pm 25.5$ & $150 \pm 12.7$ & $18 \pm 4.6$ \\
\hline \multirow[t]{6}{*}{ FPA:10 } & ST & $74 \pm 8.6$ & $\cdots$ & $\cdots$ \\
\hline & $\mathrm{OA}$ & $32 \pm 5.6$ & $\cdots$ & $5 \pm 2.2$ \\
\hline & $\mathrm{B}$ & $2 \pm 0.4$ & $\cdots$ & $\cdots$ \\
\hline & G & $\cdots$ & $6 \pm 1.4$ & $22 \pm 4.7$ \\
\hline & MM & $\cdots$ & $86 \pm 9.3$ & $\cdots$ \\
\hline & Total & $108 \pm 14.6$ & $92 \pm 10.7$ & $27 \pm 6.9$ \\
\hline \multirow[t]{3}{*}{ SAA } & os & $70 \pm 8.4$ & $\ldots$ & $\mathrm{n} / \mathrm{a}$ \\
\hline & OSp & $22 \pm 4.7$ & $52 \pm 5.2$ & $\mathrm{n} / \mathrm{a}$ \\
\hline & Total & $92 \pm 13.1$ & $52 \pm 5.2$ & $\mathrm{n} / \mathrm{a}$ \\
\hline
\end{tabular}

Note: Colony Morphotype: PR: Pale-yellow, rugose; PO: Pale-yellow, oily; Y: yellow; ST: slimy, translucent; OA: opaline, asterial; B: brown; G: grey; OS: opaline, slimy; OO: opaline, oily; OSp: opaline, spot, "..." no colonies of this morphotype, "n/a" not available. 


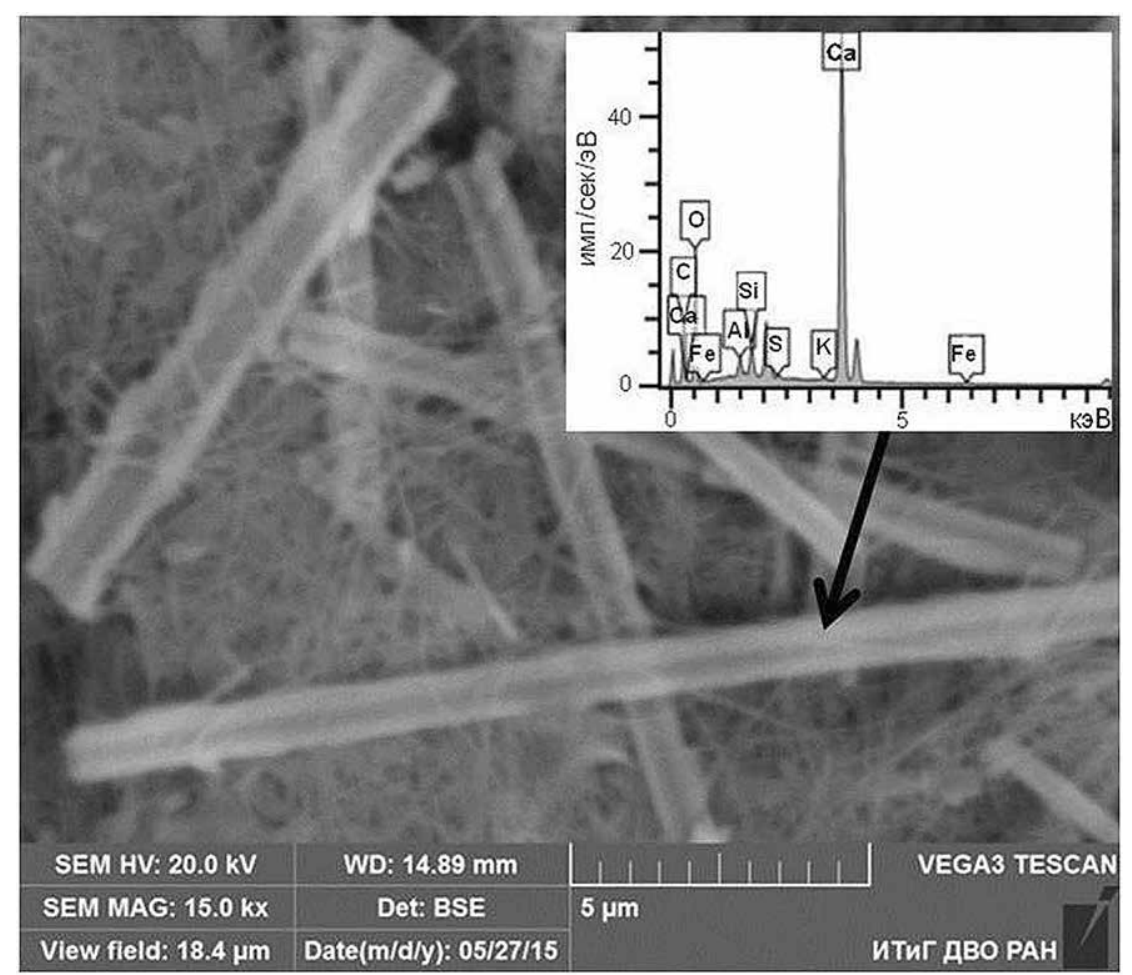

Figure. 5. SEM image and elemental composition of tubular microstructures in the composition of moonmilk, immersed in a mesh matrix. Magnification: 15,000x.

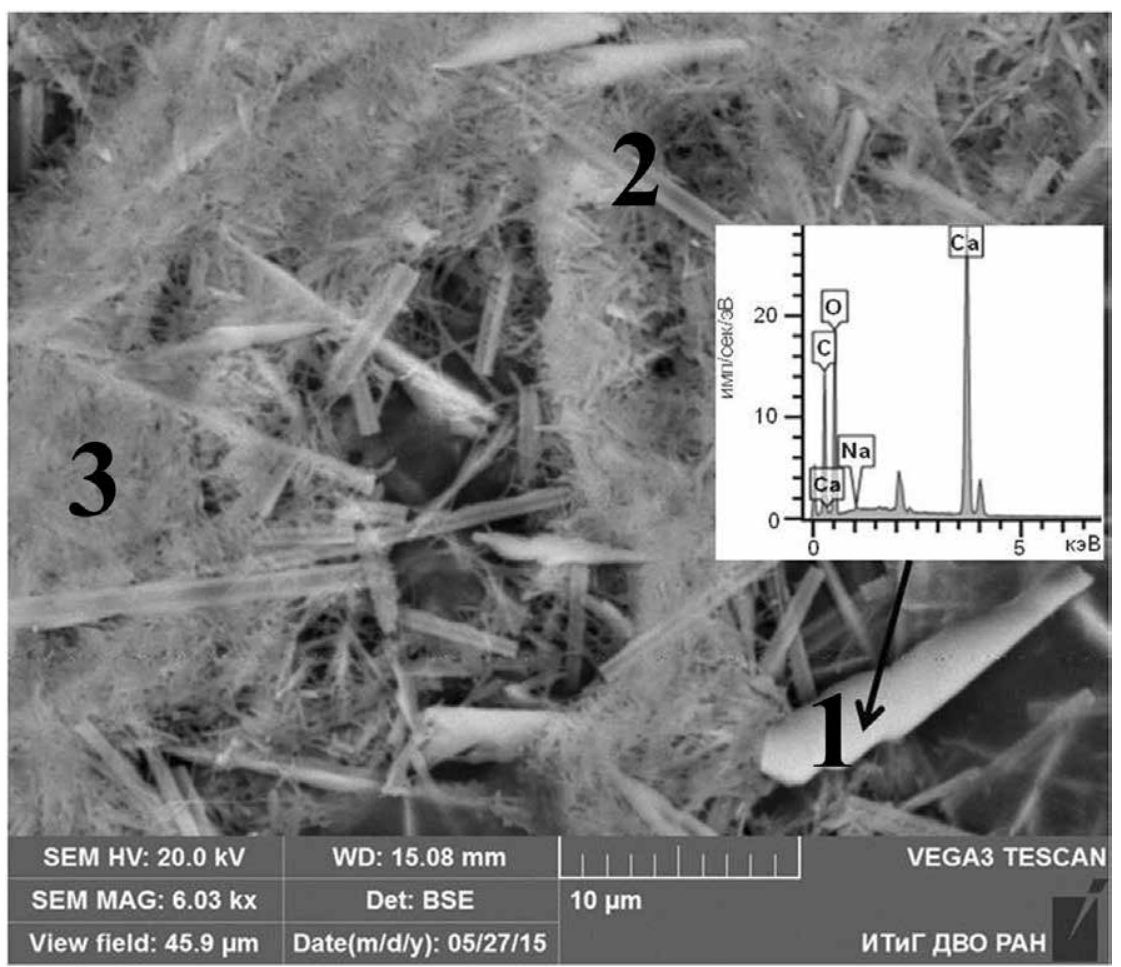

Figure. 6. SEM images of microtructures of moonmilk speleothem in the Proschalnaya Cave: (1) claviform, (2) tubular microstructures, and (3) nanofibres. Magnification: $6000 x$. and Ferris, 2006), and take an active part in induced calcium carbonate precipitation (Achal and Pan, 2014).

Molecular investigations of moonmilk sampled from the Proschalnaya Cave revealed the presence of iron bacteria

of the genera Rhodoferax and Geothrix (Table 3) that are commonly found in iron-containing groundwater. Members of substances (NOS) and differing slightly in the dominant morphotype of the colonies. Moreover, in a thin layer of curdy mass the abundance of different groups was higher than in a thicker layer of moonmilk. During cultivation on SAA containing starch as a carbon source, the abundance of bacteria was low in three samples. Periodically, violet-colored colonies, growing on Bromfield media containing $\mathrm{Fe}(\mathrm{OH})_{3}$, were isolated from moonmilk. Such differences can be associated with different stages of the formation of biofilms from moonmilk and physico-chemical conditions at the sampling sites.

Minimal diversity of colony morphotypes and low abundance were recorded in the sample of dense slimy moonmilk. There is evidence that the structure of the microbial community strongly affects the intensity of $\mathrm{CaCO}_{3}$ deposition and the composition of moonmilk (Cirigliano et al., 2018). High concentrations of calcium carbonate are able to precipitate in the slimy matrix and inhibit the development of bacteria. The physiological adaptation of bacteria to toxic $\mathrm{Ca}^{2+}$ ions occurs by calcification in $\mathrm{Ca}^{2+}$-rich cave environments. Such activity creates the initial crystal nucleation sites that contribute to the formation of secondary $\mathrm{CaCO}_{3}$ deposits within caves (Banks et al., 2010).

On the basis of cultural-morphological characteristics and a proposed scheme for identification of bacteria of the genus Bacillus (Vasiliev, 2013) with use of a series of tests (growth on citrate, arabinose, xylose, mannitol, urea, raffinose; catalase activity, and $\mathrm{H}_{2} \mathrm{~S}$ secretion). Among the twenty strains isolated from moonmilk in the Proschalnaya Cave, two strains were identified as Bacillus. It can be assumed the surface waters that drain the soil and karst rocks can act as the main source determining the composition of moonmilk. Bacillus are capable of producing polymeric slime and act as catalysts for the biogenic mineralization and weathering of rocks (Ercole et al., 2007). Bacillus can act as typical soil chemo-organotrophic bacteria that occur in freshwater, participate in the nitrogen cycle, and can reduce iron (Garcia et al., 2016). These bacteria are the centers of crystal formation, affect the morphology of crystals, the solubility of carbonates (Mitchel 
Table 3. Molecular genetics (qPCR) analysis of moonmilk, sampled from the Proschalnaya cave.

\begin{tabular}{cccc} 
Sample Description & $\begin{array}{c}\text { Total number of eubacterial } \\
\text { DNA gene copies/g }\end{array}$ & $\begin{array}{c}\text { Number of the Rhodoferax } \\
\text { DNA gene copies/g }\end{array}$ & $\begin{array}{c}\text { Number of the Geothrix } \\
\text { DNA gene copies/g }\end{array}$ \\
\hline M1: thin slimy white mass & $1.17 \times 10^{9}$ & $5.64 \times 10^{6}$ & $3.25 \times 10^{5}$ \\
M2: thick curdy ivory-white mass & $1.08 \times 10^{9}$ & $1.44 \times 10^{6}$ & $3.76 \times 10^{5}$ \\
\hline
\end{tabular}

Table 4. Elemental composition of nanostructures included in the composition of moonmilk in the Proschalnaya Cave.

\begin{tabular}{|c|c|c|c|}
\hline \multirow[b]{2}{*}{ Elements } & \multicolumn{3}{|c|}{ Weight Percent } \\
\hline & Tubular Nanostructure & Claviform Nanostructure & Nanofibres \\
\hline C & $19 \pm 1$ & $22 \pm 2$ & $41.5 \pm 1.5$ \\
\hline $\mathrm{O}$ & $59 \pm 1$ & $65 \pm 3$ & $64 \pm 2$ \\
\hline $\mathrm{Ca}$ & $17.5 \pm 2.5$ & $9.5 \pm 3.5$ & $12.5 \pm 2.5$ \\
\hline $\mathrm{Na}$ & $\cdots$ & $0.325 \pm 0.175$ & $0.91 \pm 0.41$ \\
\hline $\mathrm{Fe}$ & $0.22 \pm 0.04$ & $\cdots$ & $\cdots$ \\
\hline $\mathrm{Mn}$ & $0.105 \pm 0.005$ & $\cdots$ & $\cdots$ \\
\hline $\mathrm{Si}$ & $0.87 \pm 0.17$ & $\cdots$ & $0.135 \pm 0.055$ \\
\hline $\mathrm{Al}$ & $0.63 \pm 0.1$ & $\cdots$ & $\cdots$ \\
\hline $\mathrm{S}$ & $0.06 \pm 0.01$ & $\cdots$ & $0.505 \pm 0.245$ \\
\hline
\end{tabular}

the genus Rhodoferax are psychrotolerant facultative anaerobes that often use $\mathrm{Fe}(\mathrm{OH})_{3}$ as an electron acceptor (Finnerant et al., 2003). Geothrix fermentans is found within the Fe (III) reduction zone of subsurface environments. Such iron bacteria have been shown to attach to the surface of mineral particles by the production of adhesive biopolymer (Nevin and Lovley, 2002). We assume that Rhodoferax and Geothrix acting as primary colonizers, initiate the first stage of biofilm formation and create conditions favorable for the growth of other heterotrophic bacteria in moonmilk.

Bacteria capable of oxidizing iron and manganese have been repeatedly found in cave sediments. The presence of Flavobacterium spp. in the Iron Curtain Cave indicates that it might potentially participate in iron oxidation (Ghosh et al., 2017). Flavobacterium spp. was previously reported in abundance in ferromanganese deposits from the caves of the Upper Tennessee River Basin, along with other bacteria indicating that this bacterium contributed to Mn (II) oxidation (Carmichael et al., 2013).

Calcium salts promoting aggregation of bacterial cells and formation of slimy polymers can accelerate the formation of biofilms and their interaction with rocks (Das et al., 2014). In many cases, microorganisms and their extracellular polymeric substances act as effective centers for the formation of new structures that can lead to passive incrustation of biofilms (Flemming, 2016) and affect the structure of the speleothem (Sallstedt et al., 2014). The production of carbonic anhydrase, the enzyme regulating the equilibrium of inorganic carbon forms such as bicarbonate, can play the key role in the mechanism of biomineralization (Smith and Ferry, 2000; Müller et al., 2014).

\section{Microstructure and elemental composition of the moonmilk from the Proschalnaya Cave}

While speleologists, geologists, and microbiologists have different views on moonmilk genesis, modern research techniques have revealed an important role of biogenic factors in development of a number of sinter formations. Scanning electron microscopy (SEM) of moonmilk from the Grotta Nera Cave (Italy) revealed fibrous formations with calcites identified by X-ray refractometry (Cacchio et al., 2014). An array of elements were detected in the moonmilk, including $\mathrm{Ca}, \mathrm{Mg}, \mathrm{Al}, \mathrm{P}, \mathrm{Si}, \mathrm{S}, \mathrm{Mn}, \mathrm{K}$, and $\mathrm{Fe}$. The proportion of $\mathrm{CaO}$ was as high as $60.87 \%$ in some samples, while the portion of oxides such as $\mathrm{MgO}$ and $\mathrm{Al}_{2} \mathrm{O}_{3}$ never exceeded $1 \%$.

SEM imaging of moonmilk from the Proshchalnaya Cave showed the presence of morphologically distinct microstructures with different elemental composition. Tubular structures in the composition of moonmilk (Fig. 5) distinguished themselves by a rich chemical content. Except for the basic elements indicative of their carbonate genesis $(\mathrm{C}, \mathrm{O}$, and $\mathrm{Ca}$ ), in tubular structures $\mathrm{Al}, \mathrm{Si}$, and $\mathrm{Fe}$ were also present. In one of the loci, impurities of magnesium and sulfur were observed. Al and $\mathrm{Si}$ oxides are often found as impurities in dolomite $\left(\mathrm{CaMg}\left(\mathrm{CO}_{3}\right)_{2}\right)$, which is represented as inclusions in calcite and as part of fine-grained sediments, including in moonmilk (Hill and Forti, 2007). Similar tubular structures called nanofibres were found in caves and relate to secondary calcites (Bindschedler et al., 2014).

Calcium content in different samples of moonmilk from Snezhnaya Cave (Russia, Western Caucasus) indicated differences in nanostructures (Kondratyeva et al., 2016). The highest calcium content (up to $61.54 \%$ by weight) was observed in the cubic crystal microstructures. In this locus, the contents of carbon and magnesium oxides were $33.79 \%$ 
and $3.26 \%$ by weight, respectively. The highest level of carbon oxides (58.62 \% to $82.73 \%$ by weight) characterized the biofilm microstructures. These microstructures also had elevated levels of magnesium oxides (up to $16 \%$ by weight). Detailed scanning of the images of moonmilk from Snezhnaya Cave moonmilk revealed specific microstructures resembling stacks of thin lamellars. Elemental composition of these plates was characterized by relatively low calcium content ( $0.1-0.14 \%$ by weight) and considerably high magnesium content (14.65-22.6 \% by weight).

In a Belgian Cave (Collembola Cave), abundant, randomly-oriented, single-crystal rods, and polycrystalline calcite fibers were present in the structure of moonmilk (Maciejewska et al., 2017). The tubular microstructures in moonmilk from the Proschalnaya Cave had high similarity with these microstructures. Also SEM images of the microstructures in moonmilk from the Proschalnaya Cave were similar to calcitic nanofibres, needle fibre calcite, tubular- and filament-like structures in other scientific literature (Shankar and Achyuthan, 2007; Maciejewska et al., 2015). However, the tubular nanostructures found by us are not similar to the reticulated filaments described earlier (Melim et al., 2008).

Various mechanisms for the formation of nanostructures are proposed: physicochemical processes, such as the deposition of salts on the cell surface or the deposition of calcite crystals on organic matrices; and calcination of fungal mycelium or actinobacteria (Bindschedler et al., 2014; Maciejewska et al., 2015). Proteobacteria, Acidobacteria, and Actinobacteria were the most common phyla in strong association with the needle calcite in moonmilk (Cirigliano et al., 2018).

Needle calcite is a common secondary speleothem (Cailleau et al., 2009). The presence of calcitic nanofibers and needle calcite in secondary $\mathrm{CaCO}_{3}$ sediments can be used to characterize the paleoclimate and assess the ecological situation (Shankar and Achyuthan, 2007). Their ratio can indicate the alternation of arid and semi-arid climatic conditions, although both forms of calcite can also occur in a humid climate (Bindschedler et al., 2012).

For the first time in the mass of moonmilk in the Proschalnaya Cave we discovered claviform nanostructures (Fig. 6). In comparison with tubular structures, they have limited elemental composition (Table 4). The dominant components in these structures are carbon, oxygen, and calcium, but the calcium content in claviform nanostructure is lower than in tubular structures and nanofibers.

In some crystals of ancient calcites, needle structures composed of aragonite $\left(\mathrm{CaCO}_{3}\right)$ are found. It is assumed that, depending on the environmental conditions, sequential precipitation of calcite-aragonite-calcite can occur. The formation of aragonite in speleothems is associated with a high $\mathrm{Mg} / \mathrm{Ca}$ ratio in the drip water, as $\mathrm{Mg}$ is an inhibitor of calcite growth (Wassenburg et al., 2012). In the nanotubes and claviform microstructures we observed that Mg was extremely rare. We assumed that during the formation of the moonmilk mass against the background of a decrease in the amount of rainfall, precipitation of calcites without magnesium occurred, in spite of its presence in groundwater.

\section{Conclusions}

The nature of the interaction of groundwater and surface water varies greater under the influence of the biochemical activity of microorganisms. Due to the movement of waters and the biochemical activity of microorganisms, the most intensive dissolution of the bedrock occurs in the spring, resulting in an increase in the calcium content where fracture and drip water interact with rock. Based on our studies, we assume that the formation of moonmilk in Proschalnaya Cave largely depends on the rate of entry of organic substances and the ratio of elements accumulating in bacterial polymers. Consequently, the movement of surface water and groundwater in the area of Proschalnaya Cave drive the biogeochemical processes important for the formation of moonmilk, and the origin of the water can dictate the mineral composition of the speleothems.

Climatic conditions are an important factor affecting the speed and stages of the formation of the biomass of moonmilk. Microorganisms are producers of polymeric compounds; they act as first settlers in the initial stages of the formation of the biofilm from moonmilk, and then accumulate other elements, forming biominerals. The biospheric approach to the moonmilk speleothem study is based on interdisciplinary research that relies on macro processes (geological and geochemical) and micro processes occurring at the scale of microbial cells and biofilms. Calcite transformation and geomorphology of karst caves are changed due to the specific formation of biofilms. Moonmilk provides clear evidence of the role of biofilms in transformation of rocks in underground ecosystems.

\section{Acknowledgments}

The authors are grateful to V.O. Shadrin, the leader of the expedition to the Proschalnaya Cave in 2015-2017, to N.S. Konovalova for scanning electron microscopy, to O. Hershey (University of Akron, Akron Ohio, USA) for help with English translation, and to colleagues for help in sampling.

\section{References}

Achal, V. and Pan X., 2014, Influence of calcium sources on microbially induced calcium carbonate precipitation by Bacillus sp. CR2: Journal of Applied Biochemistry and Biotechnology, v. 173, no. 1, p. 307-314. https://doi.org/10.1007/s12010-014-0842-1 
Banks, E.D., Taylor, N.M., Gulley, J., Lubbers, B.R., Giarrizzo, J.G., Bullen, H.A., Hoehler, T.M., and Barton, H.A., 2010, Bacterial calcium carbonate precipitation in cave environments: a function of calcium homeostasis: Geomicrobiology Journal, v. 27, p. 444-454. https://doi. org/10.1080/01490450903485136

Barton, H.A., Taylor, M.R., and Pace, N.R., 2004, Molecular phylogenetic analysis of a bacterial community in an oligotrophic cave environment: Geomicrobiology Journal, v. 21, p. 11-20. https://doi.org/10.1080/01490450490253428

Barton, H.A. and Northup, D.E., 2007, Geomicrobiology in cave environments: past, current and future perspectives: Journal of Cave and Karst Studies, v. 69, p. 163-178.

Bersenyov, Yu.I., 1989, Karst of the Far East: Moscow, Nauka, 172 p. (in Russian)

Bindschedler, S., Cailleau, G., Braissant, O., Millière, L., Job, D., and Verrecchia, E.P., 2014, Unravelling the enigmatic origin of calcitic nanofibres in soils and caves: purely physicochemical or biogenic processes?: Biogeosciences, v. 11, p. 2809-2825. https://doi.org/10.5194/bg-112809-2014

Bindschedler, S., Millière, L., Cailleau, G., Job, D., and Verrecchia, E.P., 2012, An ultrastructural approach to analogies between fungal structures and needle fibre calcite: Geomicrobiology Journal, v. 29, p. 301-313. https://doi.org/10.1080/01490451.2011.558565

Borsato, A., Frisia, S., Jones, B., and Van der Borg, K., 2000, Calcite Moonmilk: crystal morphology and environment of formation in caves in the Italian Alps: International Journal of Sediment Research, v. 70, p. 1179-1190. https://doi.org/10.1306/032300701171

Braun, B., Schröder, J., Knecht, H., and Szewzyk, U., 2016, Unraveling the microbial community of a cold groundwater catchment system: Water Research, v. 107, p. 113-126. https://doi.org/10.1016/j.watres.2016.10.040

Cacchio, P., Ferrini, G., Ercole, C., Del Gallo, M., and Lepidi, A., 2014, Biogenicity and characterization of moonmilk in the Grotta Nera (Majella National Park, Abruzzi, central Italy): Journal of Cave and Karst Studies, v. 76, p. 88-103. https://doi.org/10.4311/2012mb0275

Cailleau, G., Verrecchia, E.P., Braissant, O., and Emmanuel, L., 2009, The biogenic origin of needle fibre calcite: Sedimentology, v. 56, p. 1858-1875. https://doi.org/10.1111/j.1365-3091.2009.01060.x

Canaveras, J.C., Cuezva, S., Sanchez-Moral, S., Lario, J., Laiz, L., Gonzalez, J.M., and Saiz-Jimenez, C., 2006, On the origin of fiber calcite crystals in moonmilk deposits: Naturwissenschaften, v. 93, p. 27-32. https://doi.org/10.1007/s00114-005-0052-3

Carmichael, M.J., Carmichael, S.K., Santelli, C.M., Strom, A., and Brauer, S.L., 2013, Mn(II)-oxidizing bacteria are abundant and environmentally relevant members of ferromanganese deposits in caves of the upper Tennessee river basin: Geomicrobiology Journal, v. 30, p. 779-800. https://doi.org/10.1080/01490451.2013.769651

Chelius, M.K., Beresford, G., Horton, H., Quirk, M., Selby, G., Simpson, R.T., Horrocks, R., and Moore, J.C., 2009, Impacts of alterations of organic inputs on the bacterial community within the sediments of Wind Cave, South Dakota, USA: International Journal of Speleology, v. 38, p. 1-10. https://doi.org/10.5038/1827-806x.38.1.1

Chen, Y., Wu, L., Boden, R., Hillebrand, A., Kumaresan, D., and Moussard, H., 2009, Life without light: microbial diversity and evidence of sulfurand ammoniumbased chemolithotrophy in Movile cave: Journal of the International Society for Microbial Ecology, v.3, no. 9, p. 1093-1104. https://doi.org/10.1038/ismej.2009.57

Cirigliano, A., Tomassetti, M.C., Di Pietro, M., Mura, F., Maneschi, M.L., Gentili, M.D., Cardazzo, B., Arrighi, C., Mazzoni, C., Negri, R., and Rinaldi, T., 2018, Calcite moonmilk of microbial origin in the Etruscan Tomba degli Scudi in Tarquinia: Italy Scientific Reports, v. 8, no. 1, p. 1-10. https://doi.org/10.1038/s41598-018-34134-y

Das, T., Sehar, S., Koop, L., Wong, Y.K., and Ahmed, S., 2014, Influence of calcium in extracellular DNA mediated bacterial aggregation and biofilm formation: Plos One, v. 9, no. 3, p. 1-11. https://doi.org/10.1371/journal.pone.0091935

De Mandal, S., Chatterjee, R., and Kumar, N.S., 2017, Dominant bacterial phyla in caves and their predicted functional roles in C and N cycle: BMC Microbiology, v. 17, no. 1, p. 1-9. https://doi.org/10.1186/s12866-017-1002-x

Egorov, N.S., 1995, Microbiology Practice Guidance: Moscow, MGU, 224 p. (in Russian)

Ercole, C., Cacchio, P., Botta, A.L., Centi, V., and Lepidi, A., 2007, Bacterially induced mineralization of calcium carbonate: the role of exopolysaccharides and capsular polysaccharides: Microscopy and Microanalysis, v. 13, p. 42-50. https://doi.org/10.1017/s1431927607070122

Federation Regulation F 14.1: 2: 4.143-98, 2011 ed., Quantitative chemical analysis of water. Method for measuring the mass concentration of aluminum, barium, boron, iron, potassium, calcium, cobalt, magnesium, manganese, copper, sodium, nickel, strontium, titanium, chromium and zinc in drinking, natural and waste waters by ICP spectrometry method, FR.1.31.2013.13911; https://www.russiangost.com/p-275435fr131201313911.aspx

Ferris, F.G., 2005, Biogeochemical properties of bacteriogenic iron oxides: Geomicrobiology Journal, v. 22, no. 3-4, p. 79-85. https://doi. org/10.1080/01490450590945861

Finnerant, K.T., Johnsen, C.V., and Lovley, D.R., 2003, Rhodoferax ferrireducens sp. nov., a psychrotolerant, facultatively anaerobic bacterium that oxidizes acetate with the reduction of Fe (III): International Journal of Systematic and Evolutionary Microbiology, v. 53, p. 669-673. https://doi.org/10.1099/ijs.0.02298-0

Flemming, H.C., 2016, EPS—then and now: Microorganisms, v. 4, no. 4, 41 p. https://doi.org/10.3390/microorganisms4040041

Fornós, J.J., Ginés, J., Gràcia, F., Merino, A., Gómez-Pujol, L., and Bover, P., 2014, Cave deposits and sedimentary processes in Cova des Pas de Vallgornera (Mallorca, Western Mediterranean): International Journal of Speleology, v. 43, no. 2, p. 159-174. http://dx.doi. org/10.5038/1827-806X.43.2.5

Garcia, G.M., Márquez, G.M.A., and Moreno, H.C.X., 2016, Characterization of bacterial diversity associated with calcareous deposits and drip-waters, and isolation of calcifying bacteria from two Colombian mines: Microbiological Research, v. 182, p. 21-30. https://doi. org/10.1016/j.micres.2015.09.006

Gerhardt, F., 1983, General Bacteriology Methods: Moscow, Mir, 536 p. (in Russian)

Ghosh, S., Paine, E., Wall, R., Kam, G., Lauriente, T., Sangarmangkang, P.C., Derrick Horne, D., and Cheeptham, N., 2017, In situ cultured bacterial diversity from iron Curtain Cave, Chilliwack, British Columbia, Canada: Diversity, v. 9 , no. 3, p. 1-15. https://doi.org/10.3390/d9030036

Hill, C.A. and Forti, P., 2007, Cave mineralogy and the NSS: past, present, future: Journal of Cave and Karst Studies, v. 69, p. 35-45.

Kondratyeva, L.M., Polevskaya, O.S., Litvinenko, Z.N., Golubeva, E.M., and Konovalova, N.S., 2016, Role of the microbial community in formation of speleothem (moonmilk) in the Snezhnaya karst cave (Abkhazia): Microbiology (Moscow), v. 85, no. 5, p. 629-637. https://doi. org/10.1134/s002626171605009x

Kubista, M., Andrade, J.M., Bengtsson, M., Forootan, A., Jonake, J., Lind, K., Sindelka, R., Sjoback, R., Sjogreen, B., Strombom, L., Stahlberg, A., and Zoric, N., 2006, The real-time polymerase chain reaction: Molecular Aspects of Medicine, v. 27, p. 95-125. https://doi.org/10.1016/j. mam.2005.12.007

Kuhn, K.M., DuBois, J.L., and Maurice, P.A., 2014, Aerobic microbial Fe acquisition from ferrihydrite nanoparticles: effects of crystalline order, siderophores, and alginate: Environmental Science and Technology, v. 48, no. 15, p. 8664-8670. https://doi.org/10.1021/es501308b 
Kuznetsov, S.I. and Dubinina, G.A., 1989, Methods for the Study of Aquatic Microorganisms: Moscow, Nauka, 288p. (in Russian)

Lefevre, E., Bossa, N., Wiesner, M.R, and Gunsch, C.K., 2016, A review of the environmental implications of in situ remediation by nanoscale zero valent iron (nZVI): behavior, transport and impacts on microbial communities: Science of the Total Environment, v. 565, p. 889-901. https://doi.org/10.1016/j.scitotenv.2016.02.003

Maciejewska, M., Adam, D., Naômé, A., Martinet, L., Tenconi, E., Całusińska, M., Delfosse, P.,

Müller, W.E., Schlossmacher, U., Schröder, H.C., Lieberwirth, I., Glasser, G., Korzhev, M., Neufurth, M., and Wang, X., 2017, Enzyme-accelerated and structure-guided crystallization of calcium carbonate: role of the carbonic anhydrase in the homologous system: Acta Biomaterialia, $v$. 10, no.1, p. 450-462. https://doi.org/10.3389/fmicb.2017.01181

Maciejewska, M., Pessi, I.S., Arguelles-Arias, A., Noirfalise, P., Luis, G., Ongena, M., Barton, H., Carnol, M., and Rigali, S., 2015, Streptomyces Iunaelactis sp. nov., a novel ferroverdin A-producing Streptomyces species isolated from a moonmilk speleothem: Antonie van Leeuwenhoek, v. 107, no. 2, p. 519-531. https://doi.org/10.1007/s10482-014-0348-4

Margesin, R., 2009, Effect of temperature on growth parameters of psychrophilic bacteria and yeasts: Extremophiles, v. 13, no. 2, p. $257-262$. https://doi.10.1007/s00792-008-0213-3

Melim, L. A., Northup, D. E., Spilde, M. N., Jones, B., Boston, P. J., and Bixby, R. J, 2008, Reticulated filaments in cave pool speleothems: microbe or mineral?: Journal of Cave and Karst Studies, v. 70, p. 135-141. https://doi.org/10.7939/R3J38KZ7V

Mitchell, A.C. and Ferris F.G., 2006, The influence of Bacillus pasteuriion the nucleation and growth of calcium carbonate: Geomicrobiology Journal, v. 23, p. 213-226. https://doi.org/10.1080/01490450600724233

Müller, W.E., Schlossmacher, U., Schröder, H.C., Lieberwirth, I., Glasser, G., Korzhev, M., Neufurth, M., and Wang, X., 2014, Enzyme-accelerated and structure-guided crystallization of calcium carbonate: role of the carbonic anhydrase in the homologous system: Acta Biomaterialia, $v$. 10, no. 1, p. 450-462. https://doi.org/10.1016/j.actbio.2013.08.025

Namsaraev, B.B., Barkhutova, D.D., Khakhinov, V.V., 2006, Field workshop on aquatic microbiology and hydrochemistry: Methodical manual/ Ed M. B. Vainshtein: Moscow-Ulan-Ude, Publishing House of the Buryat State University, $68 \mathrm{p}$.

Nevin, K.P. and Lovley, D.R., 2002, Mechanisms for accessing insoluble Fe (III) oxide during dissimilatory Fe (III) reduction by Geothrix fermentans: Applied Environmental Microbiology, v. 68, no. 5, p. 2294-2299. https://doi.org/10.1128/aem.68.5.2294-2299.2002

Perry, T.D., Duckworth, O.W., McNamara, C.J., Martin, S.T., and Mitchell, R., 2004, Effects of the biologically produced polymer alginic acid on macroscopic and microscopic calcite dissolution rates: Environmental Science and Technology, v. 38, p. 3040-3046. https://doi.org/10.1021/ es035299a

Porca, E., Jurado, V., Zgur-Bertok, D., Saiz-Jimenez, C., and Pasic, L., 2012, Comparative analysis of yellow microbial communities growing on the walls of geographically distinct caves indicates a common core of microorganisms involved in their formation: FEMS Microbiology Ecology, v. 81, p. 255-266. https://doi.org/10.1111/j.1574-6941.2012.01383.x

Portillo, M.C. and Gonzales, J.M., 2011, Moonmilk deposits originate from specific bacterial communities in Altamira Cave (Spain): Microbial Ecology, v. 61, p. 182-189. https://doi.org/10.1007/s00248-010-9731-5

Reitschuler, C., Spötl, C., Hofmann, K., Wagner, A.O., and IIImer, P., 2016, Archaeal distribution in moonmilk deposits from Alpine caves and their ecophysiological potential: Microbial Ecology, v. 71, no. 3, p. 686-699. https://doi.org/10.1007/s00248-015-0727-z

Rodrigues, D.F. and Tiedje, J.M., 2008, Coping with our cold planet: Applied Environmental Microbiology, v. 74, p. 1677-1686. https://doi.10.1128/ AEM.02000-07

Sallstedt, T., Ivarsson, M., Lundberg, J., Sjöberg, R., and Vidal Romaní, J.R., 2014, Speleothem and biofilm formation in a granite/dolerite cave, Northern Sweden: International Journal of Speleology, v. 43, no. 3, p. 305-313. https://doi.org/10.5038/1827-806x.43.3.7

Shankar, N. and Achyuthan, H., 2007, Genesis of calcic and petrocalcic horizons from Coimbatore, Tamil Nadu: micromorphology and geochemical studies: Quaternary International, v. 175, p. 140-154. https://doi.org/10.1016/j.quaint.2007.05.017

Shesterkin V.P., 1983, Chemical Content of Groundwater and Ice From Proschalnaya Cave. Genesis of groundwater: Irkutsk, Institute of the Earth's Crust, 140 p. (in Russian)

Smith, K.S. and Ferry, J.G., 2000, Prokaryotic carbonic anhydrases: FEMS Microbiology Reviews, v. 24, p. 335-366. https://doi.org/10.1016/ s0168-6445(00)00030-9

Struvay, C. and Feller, G., 2012, Optimization to low temperature activity in psychrophilic enzymes: International Journal of Molecular Sciences, v.13, no. 9, p. 11643-11665. https://doi.org/10.3390/ijms130911643

Vasiliev, D.A., Kaldyrkaev, A.I., Feoktistova, N.A., and Aleshkin, A.V., 2013, Identification of Bacillus cereus Bacteria Based on Their Phenotypic Characteristics: Uliyanovsk, Nauchnoe izdanie, 98 p. (in Russian)

Velikonja, B.H., Tkavc, R., and Paši'c, L., 2014, Diversity of cultivable bacteria involved in the formation of macroscopic microbial colonies (cave silver) on the walls of a cave in Slovenia: International Journal of Speleology, v. 43, p. 45-56. https://doi.org/10.5038/1827-806x.43.1.5

Wassenburg, J.A., Immenhauser, A., Richter, D.K., Jochum, K.P., Fietzke, J., Deininger, M., Goos, M., Scholz, D., and Sabaoui, A., 2012, Climate and cave control on Pleistocene/Holocene calcite-to-aragonite transitions in speleothems from Morocco: elemental and isotopic evidence: Geochimica et Cosmochimica Acta, v. 92, p. 23-47. https://doi.org/10.1016/j.gca.2012.06.002

Wu, Y., Tan, L., Liu, W., Wang, B., Wang, J., Cai, Y., and Lin, X., 2015, Profiling bacterial diversity in a limestone cave of the western loess plateau of China: Frontiers in Microbiology, v. 6, no. 244, p. 1-10. https://doi.org/10.3389/fmicb.2015.00244 